\title{
Article/Artigo
}

\section{Risk factors for physical disability at diagnosis of 19,283 new cases of leprosy}

\author{
Fatores de risco para incapacidade física no momento do diagnóstico de 19.283 casos novos \\ de hanseníase
}
Cristiane Moschioni ${ }^{1}$, Carlos Maurício de Figueiredo Antunes ${ }^{1}$, Maria Aparecida Faria Grossi ${ }^{2}$ and José Roberto Lambertucci ${ }^{1}$

\begin{abstract}
Introduction: The purpose of this study was to evaluate risk factors for physical disability at the moment of leprosy diagnosis. Methods: This is a retrospective, descriptive and exploratory investigation of 19,283 patients with leprosy, registered in the State of Minas Gerais, Brazil, between 2000 and 2005. Results: The risk of Grade 2 disability was 16.5 -fold higher in patients with lepromatous leprosy, and 12.8-fold higher in patients presenting the borderline form, compared to patients presenting indeterminate leprosy. The occurrence of more than one thickened nerve increased the odds of a patient developing Grade 2 disability, 8.4-fold. Age $<15$ years, multibacillary leprosy and no formal education presented 7.0, 5.7 and 5.6 odds of developing physical disability, respectively. Conclusions: These factors should be considered as strong prognostic indicators in the development of physical disability at diagnosis.
\end{abstract}

Key-words: Leprosy. Physical disability. Risk factors for disability. Lepromatous leprosy. Physical disability prognosis.

\section{RESUMO}

Introdução: $\mathrm{O}$ objetivo deste estudo foi o de avaliar os fatores de risco para incapacidade física no momento do diagnóstico. Métodos: Trata-se de estudo retrospectivo, descritivo e exploratório de 19.283 pacientes com hanseníase, notificados entre 2000 e 2005, no estado de Minas Gerais, Brasil. Resultados: $O$ risco para desenvolver grau 2 de incapacidade física foi 16,5 vezes maior no paciente com hanseníase virchowiana e 12,8 vezes maior no paciente com a forma dimorfa, quando comparados aos pacientes com a forma indeterminada. A presença de mais de um nervo acometido aumentou o risco de desenvolver grau 2 de incapacidade em 8,4 vezes. A idade inferior a 15 anos, os pacientes multibacilares e a falta de escolaridade aumentaram a chance de deformidades em 7,0, 5,7 e 5,6, respectivamente. Conclusões: Estes fatores devem ser considerados indicadores importantes do prognóstico para incapacidade física no momento do diagnóstico.

Palavras-chaves: Hanseníase. Incapacidade física. Fatores de risco para deformidade. Hanseníase virchowiana. Prognóstico para incapacidade física.

\footnotetext{
1. Infectious Diseases Branch, School of Medicine, Federal University of Minas Gerais, Brazil. 2. Secretary of Health of the Minas Gerais State, Belo Horizonte, MG, Brazil.
}

Address to: Dr. José Roberto Lambertucci. Departamento de Clínica Médica/FM/UFMG. Avenida Alfredo Balena 190, 30130-100 Belo Horizonte, MG, Brazil.

Phone: 553134099820

email: lamber@uai.com.br

Received in 19/06/2009

Accepted in 06/01/2010

\section{INTRODUCTION}

Leprosy stands out for its morbidity, notwithstanding its low mortality rates, leading to physical disability, deformity, psychological disturbances, economical dependence and social exclusion ${ }^{1}$. It has been estimated that 2 million people presently live with physical incapacity as consequence of the disease ${ }^{2}$.

The elimination of leprosy, proposed by the World Health Organization (defined as a reduction of the prevalence rate to less than 1 affected person per 10,000 inhabitants) was important to redefine the activities for controlling the disease. However, many investigators, considered this as an intermediate goal, because the interruption of transmission and disease control are, in fact, the main objective . $^{3}$

The worst prognostic factor for predicting deformity is the presence of physical disability at the moment of diagnosis. Interestingly, the use of prednisone decreased morbidity in $88 \%$ of the infected subjects ${ }^{4,5}$.

The objective of this study was to identify and quantify the most important risk factors for physical disability at diagnosis.

\section{METHODS}

From 2000 to $2005,19,283$ patients with leprosy diagnosed in the State of Minas Gerais were registered in the Brazilian Health System (Sistema Nacional de Informações de Agravo de Notificação - SINAN). The information obtained was transferred to a databank using the EPI-INFO software, version 3.5.1 (CDC 2008) and analyzed using the statistical package SPSS for Windows, version 13 (SPSS Incorporated) at the Federal University of Minas Gerais, Brazil. The variables analyzed are presented in Table $\mathbf{1 .}$

Physical disability was the outcome investigated; all other variables were explanatory. The WHO 
TABLE 1 - Description of study variables obtained in SINAN's notification form, Ministry of Health, Brazil, 2000-2005.

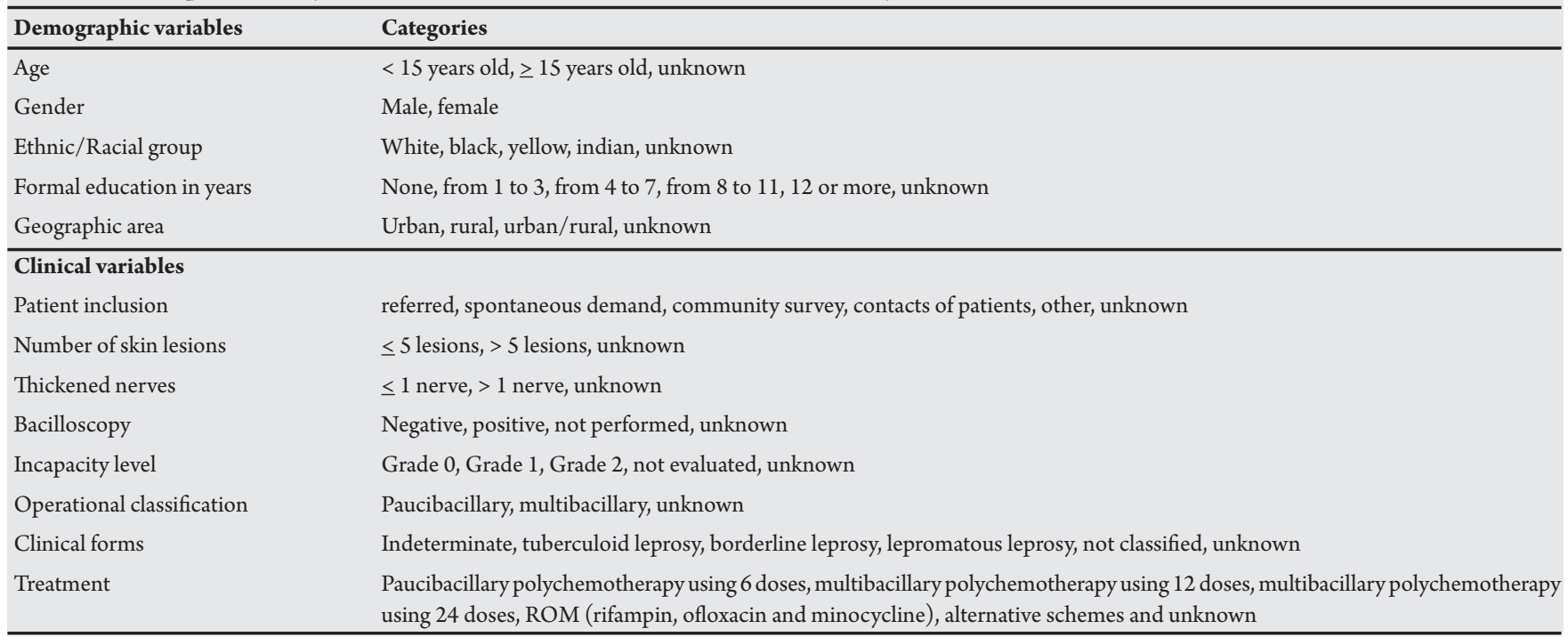

classification of physical disability in leprosy is defined in 3 categories $^{6}$ : 1) no disability (no anesthesia) and no visible deformity or damage to the eyes, hands or feet (Grade 0 ); 2) only disability (anesthesia, but no visible deformity or damage to the eyes, hands or feet) (Grade 1 ); and 3) visible deformity or damage to the eyes (lagophthalmos, iridocyclitis, corneal opacities, severe visual impairment), hands (claw hands, ulcers, absorption of the digits, thumb-web contracture and swollen hand), feet (plantar ulcers, foot-drop, inversion of the foot, clawing of the toes, absorption of the toes, collapsed foot and callosities) (Grade 2).

As there was no clear definition of skin color in the notification card this variable was excluded from analysis. Treatment was not included, because the information was obtained at diagnosis.

The multivariate analysis was adjusted in 3 distinct logistic models, as some explanatory variables were multicollinear. Among the models, the one which included thickened nerves and the clinical form was chosen because it presented a smaller confidence interval for the odds ratio.

\section{RESULTS}

All the variables presented statistically significant association with disability levels. The model used to evaluate risk factors for disability at the moment of diagnosis is presented in Table 2.

Geographic area was dropped from the model as it did not maintain statistical significance.

Lepromatous leprosy at diagnosis had the highest impact on physical disability and deformity. It increased the odds of developing grade 2 disability 16.5 -fold, whereas borderline form increased the odds 12.8 -fold, when both were compared to the indeterminate clinical form.

The occurrence of more than one thickened nerve at diagnosis increased the odds of grade 2 disability 8.4-fold compared to one thickened nerve.

The other models are not presented here, but age $<15$ years, multibacillary patients and no formal education presented 7.0, 5.7 and 5.6 odds of developing physical disability, respectively. Other variables were identified as risk factors, but with low effect on physical disability: 1 to 3 years of formal education (3.51 times), positive bacilloscopy (1.77 times), more than 5 skin lesions (1.60 times), male gender ( 1.40 times) and detection through community survey (1.24 times).

\section{DISCUSSION}

The presence of lepromatous leprosy at diagnosis showed the highest impact as a risk factor for disability and physical deformity, followed by borderline leprosy. Physical disability and deformity are seen in both clinical forms and are explained by the host immune response and the long time span of the disease before diagnosis is confirmed. When the cellular immune response is strong (tuberculoid leprosy), bacillary destruction with minimal nerve injury occurs ${ }^{7-10}$. When it is weak (lepromatous leprosy), the bacilli multiply and spread to nerve trunks ${ }^{11}$. Multibacillary leprosy and bacillary index $\geq 2$ have been reported as risk factors for neuropathy ${ }^{14}$.

Nerve damage is associated with physical disability and deformity and is considered the most severe complication of leprosy ${ }^{12,15-19}$. In our analysis, this variable presented the most precise odds for developing physical disability and deformity (95\%CI 7.41-9.68). Although it is considered a subjective variable (palpation of peripheral nerves), the number of thickened nerves should be evaluated and its prognostic importance recognized. The frequency of neuropathy increases significantly in elderly patients, in cases with late diagnosis and in patients with higher number of thickened nerves ${ }^{12,20,21}$.

Diagnosis of leprosy using community surveys (e.g., schools, nurseries, small villages) increased the detection of Grade 2 disability. This may reflect the examiners' better training, with a defined focus on verifying leprosy complications.

Aged 15 years-old and over at diagnosis was a strong risk factor for disability. Age is known to be related to disease duration and diagnosis delay $^{22,23}$, but this is the first study to quantify the association ${ }^{12,20}$. Tissue damage caused by magnified and prolonged immunological 
TABLE 2 - Multivariate model to identify risk factors for disability at the moment of leprosy diagnosis, Minas Gerais, Brazil, $2000-2005$.

\begin{tabular}{|c|c|c|c|c|c|}
\hline Variables & $\mathbf{b}^{*}$ & $\operatorname{SE}(\mathbf{b})^{+}$ & $\mathbf{O R}^{\#}$ & $95 \% \mathrm{CI} \mathrm{OR}^{\mathrm{a}}$ & p-value \\
\hline \multicolumn{6}{|l|}{ Age } \\
\hline$\geq 15$ years old & & & & 1.0 & \\
\hline$<15$ years old & -1.172 & 0.162 & 0.31 & $0.23 ; 0.43$ & 0.000 \\
\hline \multicolumn{6}{|l|}{ Gender } \\
\hline female & & & & 1.0 & \\
\hline male & 0.335 & 0.055 & 1.40 & $1.26 ; 1.56$ & 0.000 \\
\hline \multicolumn{6}{|c|}{ Formal education in years } \\
\hline none & 1.739 & 0.167 & 5.69 & $4.10 ; 7.90$ & 0.000 \\
\hline from 1 to 3 & 1.254 & 0.171 & 3.51 & $2.51 ; 4.91$ & 0.000 \\
\hline from 4 to 7 & 0.906 & 0.160 & 2.47 & $1.81 ; 3.39$ & 0.000 \\
\hline from 8 to 11 & 0.303 & 0.173 & 1.35 & $0.96 ; 1.90$ & 0.101 \\
\hline from 12 or more & & & & 1.0 & \\
\hline unknown & 0.214 & 0.443 & 1.24 & $0.52 ; 2.95$ & 0.341 \\
\hline \multicolumn{6}{|l|}{ Thickened nerves } \\
\hline$\leq 1$ nerve & & & & 1.0 & \\
\hline$>1$ nerve & 2.136 & 0.066 & 8.47 & $7.41 ; 9.68$ & 0.000 \\
\hline \multicolumn{6}{|l|}{ Clinical forms } \\
\hline lepromatous & 2.798 & 0.174 & 16.42 & $11.67 ; 23.10$ & 0.000 \\
\hline borderline & 2.551 & 0.167 & 12.82 & $9.24 ; 17.79$ & 0.000 \\
\hline tuberculoid & 1.506 & 0.177 & 4.51 & $3.18 ; 6.39$ & 0.000 \\
\hline indeterminate & & & & 1.0 & \\
\hline not classified & 3.521 & 0.474 & 33.83 & $13.35 ; 85.73$ & 0.000 \\
\hline \multicolumn{6}{|l|}{ Patient inclusion } \\
\hline spontaneous demand & 0.291 & 0.096 & 1.34 & $1.11 ; 1.62$ & 0.003 \\
\hline referred & 0.318 & 0.096 & 1.37 & 1,$14 ; 1.66$ & 0.004 \\
\hline community survey & 0.213 & 0.170 & 1.24 & $0.88 ; 1.72$ & 0.492 \\
\hline contacts & & & & 1.0 & \\
\hline others & 1.281 & 0.233 & 3.60 & $2.28 ; 5.69$ & 0.000 \\
\hline
\end{tabular}

*b: regression coefficient, ${ }^{+} \mathrm{SE}(\mathrm{b})$ : standard error, ${ }^{\mathrm{a}} \mathrm{CI}$ : confidence interval, ${ }^{\#} \mathrm{OR}$ : odds ratio.

response is reduced by early diagnosis and treatment which prevent the development of neural damage.

At diagnosis, illiteracy was associated with physical disability, as previously reported ${ }^{24,25}$. Formally educated people are more aware of their needs, seek medical attention at an earlier stage of the disease and have timely access to health system facilities ${ }^{26-29}$.

Male patients presented deformity more frequently than females and the following arguments have been proposed to explain such difference: 1) the difficulty of male subjects to come to a health facility during their working day ${ }^{30-34} ; 2$ ) the fear of losing their jobs because of the stigma of leprosy and 3) since they are more likely to be engaged in heavy physical activities the risk of deformity is increased.

In summary, the most important risk factors for physical incapacities at diagnosis, in decreasing order of importance, were: lepromatous clinical form, borderline leprosy, the presence of more than one thickened nerve and tuberculoid clinical form. A more aggressive approach is necessary to diagnose leprosy at an earlier stage, targeting the reduction of disability and deformity.

\section{CONFLICT OF INTEREST}

The authors declare that there is no conflict of interest.

\section{REFERENCES}

1. Meima A, Richardus JH, Habbema JD. Trends in leprosy case detection worldwide since 1985. Lepr Rev 2004; 75:19-33.

2. World Health Organization. Global leprosy situation, 2004. Wkly Epidemiol Rec 2005; 80:118-124.

3. Suárez REG and Lombardi C. Estimado de prevalência de lepra. Hansen Int 1997; 22: 31-34.

3. Opromolla DVA. A hanseníase após a cura [Editorial]. Hansen Int 1998; 23:1 2.

4. Smith WC, Antin US, Patole AR. Disability in leprosy: a relevant measurement of progress in leprosy control. Lepr Rev 1980; 51:155-166.

5. World Health Organization. Leprosy elimination campaigns. Wkly Epidemiol Rec 2000; 75:361-366.

6. Pfaltzgraff RE, Bryceson A. Clinical leprosy. In: Hastings RC. Leprosy. New York: Churchill Livingstone; 1985. p.134-176.

7. Spierings E, de Boer T, Wieles B, Adams LB, Marani E, Ottenhoff TH Mycobacterium leprae-specific, HLA class II-restricted killing of human Schwann cells by CD4+ Th1 cells: a novel immunopathogenic mechanism of nerve damage in leprosy. J Immunol 2001; 166:5883-5888.

8. Job CK. Pathology and pathogenesis of leprous neuritis; a preventable and treatable complication. Int J Lepr Other Mycobact Dis 2001; 69 (suppl):S19-29.

9. Garbino JA, Nery JA, Virmond M, Stump PRN, Baccarelli R, Marques Junior W. Hanseníase: diagnóstico e tratamento da neuropatia. In: Associação Médica Brasileira, Conselho Federal de Medicina. Projeto diretrizes. São Paulo: AMB 2005. p.147-59. 
10. Smith WC. The epidemiology of disability in leprosy including risk factors. Lepr Rev 1992; 63 (suppl 1):23s-30s.

11. Saunderson P, Gebre S, Desta K, Byass P, Lockwood DN. The pattern of leprosyrelated neuropathy in the AMFES patients in Ethiopia: definitions, incidence, risk factors and outcome. Lepr Rev 2000; 71:285-308.

12. Solomon S, Kurian N, Ramadas P, Rao PS. Incidence of nerve damage in leprosy patients treated with MDT. Int J Lepr Other Mycobact Dis 1998; 66:451-456.

13. Rodrigues ALP, Almeida AP, Rodrigues BF, Pinheiro CA, Borges DS, Mendonça $\mathrm{MLH}$, et al. Occurrence of late lepra reaction in leprosy patients: subsidies for implementation of a specific care program. Hansen Int 2000; 25:17-25.

14. Croft RP, Richardus JH, Nicholls PG, Smith WC. Nerve function impairment in leprosy: design, methodology, and intake status of a prospective cohort study of 2664 new leprosy cases in Bangladesh (The Bangladesh Acute Nerve Damage Study). Lepr Rev 1999; 70:140-159.

15. Zhang G, Li W, Yan L, Yang Z, Chen X, Zheng T, et al. An epidemiological survey of deformities and disabilities among 14,257 cases of leprosy in 11 counties. Lepr Rev 1993; 64:143-149.

16. Irgens LM. Leprosy in Norway: an epidemiological study based on a national patient registry. Lepr Rev 1980; 51(suppl 1):i-xi, 1-130.

17. Kushwah SS, Govila AK, Kushwah J. An epidemiological study of disabilities among leprosy patients attending leprosy clinic in Gwalior. Leprosy 1981; 53:240-247.

18. Sehgal VN, Sharma PK. Pattern of deformities/disabilities in urban leprosy. Indian J Lepr 1985; 57:183-92.

19. Foss NT, Souza CS, Goulart IMB, Gonçalves HS, Virmond M. Hanseníase: episódios reacionais. In: Associação Médica Brasileira, Conselho Federal de Medicina. Projeto diretrizes. São Paulo: AMB; 2005. p.161-179.

20. Van Brakel WH, Khawas IB. Nerve damage in leprosy: an epidemiological and clinical study of 396 patients in west Nepal. Part 1. Definitions, methods and frequencies. Lepr Rev 1994; 65:204-21.

21. Irgens LM, Skjaerven R. Secular trends in age at onset, sex ratio, and type index in leprosy observed during declining incidence rates. Am J Epidemiol 1985; 122:695-705.

22. Jain S, Reddy RG, Osmani SN, Lockwood DN, Suneetha S. Childhood leprosy in an urban clinic, Hyderabad, India: clinical presentation and the role of household contacts. Lepr Rev 2002; 73:248-253.

23. Li HY, Pan YL, Wang Y. Leprosy control in Shandong Province, China, 19551983; some epidemiological features. Int J Lepr Other Mycobact Dis 1985; 53:79-85.

24. Reddy BN, Bansal RD. An epidemiological study of leprosy disability in a leprosy endemic rural population of Pondicherry (south India). Indian J Lepr 1984; 56:191-199.

25. Kartikeyan S, Chaturvedi RM. Pattern of leprosy deformities among agricultural labourers in an endemic district: a pilot study. Indian J Lepr 1992; 64:375-379.

26. Kaur H, Van Brakel W. Dehabilitation of leprosy-affected people: a study on leprosy-affected beggars. Lepr Rev 2002; 73:346-355.

27. Noordeen SK. Epidemiology and control of leprosy-a review of progress over the last 30 years. Trans R Soc Trop Med Hyg 1993; 87:515-517.

28. Rao PS, Karat S, Karat AB, Furness MA. Prevalence of deformities and disabilities among leprosy patients in an endemic area. I. General findings. Int J Lepr Other Mycobact Dis 1970; 38:1-11.

29. Chen XS, Li WZ, Jiang C, Ye GY. Leprosy in China: epidemiological trends between 1949 and 1998. Bull World Health Organ 2001; 79:306-312.

30. Lombardi C, Martolli CM, Silva SA, Suárez RE. Eradication of leprosy in the

31. Americas: current status and perspectives. Rev Panam Salud Publica. 1998; 4:149-155.

32. Goulart IMB, Dias CM, Oliveira ACS, Silva AA, Alves RR, Quaresemin CR, et al. Grau de incapacidade: indicador de prevalência oculta e qualidade do programa de controle da hanseníase em um Centro de Saúde-Escola no município de Uberlândia - MG. Hansen Int 2002; 27:5-13.

33. Prata PB, Bohland AK, Vinhas SA. Aspectos epidemiológicos da hanseníase em localidades do Estado de Sergipe, Brasil, período de 1994-1998. Hansen Int 2000; 25:49-53.

34. Wu XS, Ning Y, Shi L, Jin Z, Yang JW. An epidemiological analysis of leprosy from 1951-1996 in Sichuan. Indian J Lepr 2000; 72:215-226. 